\title{
THE IMPACT OF IMMIGRATION ON PRODUCTIVITY
}

\author{
Joan Llull
}

CEMFI Working Paper No. 0802

February 2008

CEMFI

Casado del Alisal 5; 28014 Madrid

Tel. (34) 914290 551. Fax (34) 914291056

Internet: www.cemfi.es

This paper is a revised version of my M.Phil. Thesis presented at CEMFI. I am very grateful to Stéphane Bonhomme for his incredible supervision. I would also like to thank Juan Braun for mailing me his PhD Dissertation. I acknowledge very useful comments and discussion from Marco Alfano, Samuel Bentolila, Guillermo Caruana, José L. Groizard, Claudio Michelacci, Pedro Mira, Josep Pijoan-Mas, Joan C. Rosselló and, specially, Manuel Arellano. Finally, I thank participants at the Spanish Prime Minister Economic Boreau (OEP) seminar, at CEMFI sessions and at XXXII Simposio de Análisis Económico (SAE2007) held in Granada. A previous version of this paper circulated under the title "The Impact of Immigration on Economic Growth". 
CEMFI Working Paper 0802

February 2008

\title{
THE IMPACT OF IMMIGRATION ON PRODUCTIVITY
}

\begin{abstract}
This paper provides cross-country macro evidence on the effect of immigration on productivity. It combines panel data with instrumental variables to correct for OLS biases due to reverse causality. In particular, it introduces push-targeting instruments; they constitute a new approach to find dynamic instruments based on gravity equations that are suitable to be used in panel data settings with fixed effects. Another methodological contribution is the aggregation of instruments as a solution to the lack of bilateral migration data. Results suggest a negative impact of immigration on productivity that is partially offset by a positive effect on participation and employment.
\end{abstract}

JEL Codes: F22, O40, J61.

Keywords: Immigration, productivity, gravity equations, instrumental variables, panel data.

Joan Llull

CEMFI

Joan.llull@cemfi.es 


\section{Introduction}

Immigration into OECD countries has risen in the last decade. According to UN data (United Nations, 2006), the average proportion of immigrants in the OECD population rose from $4 \%$ in 1960 to $10 \%$ in 2005 . Understanding the consequences of this inflow of workers is a matter of concern for governments and economists. The present investigation contributes to this debate by analyzing the impact of immigration on productivity. Moreover, it also focuses on two additional components of GDP per capita: employment and participation.

The results of the present analysis suggest a negative impact of immigration on productivity. Point estimates indicate that an immigrant produces two thirds of the efficiency units of a native. This negative outcome, however, is partially offset by positive effects on participation and employment. Therefore, immigration has a very small effect on GDP per capita. Nevertheless, this result does not take long run adjustments like changes in saving and investment behaviors or a change in natives' investment in education into account ${ }^{1}$.

Immigration is likely to be endogenous in a productivity regression. The present paper uses instrumental variables and panel data techniques to obtain interpretable results. Gravity equations are exploited to generate instruments, following the approach introduced by Frankel and Romer (1999) in the trade literature. They use exogenous geographic determinants of trade in a bilateral regression and aggregate the fitted values to instrument trade in a GDP per capita equation.

However, there are two major problems for using this approach in a migration panel setting. On the one hand, bilateral migration data are not available for most of the countries and periods. To solve this problem, the present paper introduces a new approach based on aggregation of instruments.

On the other hand, geographic instruments are constant over time and they cannot be used in a panel data setting with fixed effects. To solve this, the present article introduces the push-targeting approach. Under this methodology, each instrument consists in the multiplication of a push and a targeting variable. The former is an exogenous determinant of the migration decision; typically, this kind of instruments captures a shock for the source country that motivates migration

\footnotetext{
1 Barro and Sala-i-Martín (1995) and Braun (1993) are examples of macroeconomic neoclassical growth models with migration that show how transitional dynamics and other adjustments work. Barro and Sala-i-Martín (1992) present additional empirical evidence. See Drinkwater et al. (2003) for a survey.
} 
(e.g., political regime, the presence of a conflict or the population growth). The latter is a geographic determinant of the choice of the destination country (examples are the physical distance between the countries, countries' size or having a common language/a past colonial relationship). Push variables have variance across origins and over time, while targeting ones are constant over time but vary across origins and destinations. Therefore, push-targeting instruments have the necessary variance across destinations and over time to provide identification.

Push-targeting instruments (and aggregation) constitute the methodological contribution of this paper. They may have applications in other topics. In particular, they may be used in the field of international trade to extend the literature introduced by Frankel and Romer (1999) to panel data techniques. Moreover, they can be used in the spatial correlations approach as an alternative to the instruments based on the stock of immigrants at the beginning of the period, introduced by Altonji and Card (1991).

The research on the consequences of immigration is often approached from the perspective of labor economics. In particular, most of the investigation concentrates in testing the effect of immigration on wages. Early work based on simple supply and demand models used the spatial correlations approach to emphasize that immigration reduced productivity and wages due to diminishing returns to labor (Borjas (1999) and Friedberg and Hunt (1995) are good surveys of this literature). However, recent structural estimates based on CES production functions show potentially positive effects. Immigration in a specific education-experience cell may involve complementarities with differently skilled native labor force, increasing its productivity. These complementarities may turn into a less negative or even positive overall effect of immigration on wages (see, for instance, Borjas (2003) and Ottaviano and Peri (2006)). The evidence showed in the present paper is obtained with a very different approach and has to be considered as a complement to this literature.

The remainder of the paper is organized as follows. Section 2 describes the model that is estimated and the empirical strategy used. Data issues are presented in Section 3 and Section 4 show the results before concluding in Section 5 . 


\section{Empirical strategy}

\section{$2.1 \quad$ The model}

The present paper considers a simple open economy model in which a firm maximizes an aggregate production function with two factors of production (capital and efficiency units of labor):

$$
Y_{i, t}=F\left(K_{i, t}, L_{i, t}^{*}\right)=K_{i, t}^{\alpha}\left(\theta_{M} M_{i, t}+\theta_{N} N_{i, t}\right)^{1-\alpha} .
$$

$Y_{i, t}$ is the total output of the country $i$ at time $t, K_{i, t}$ represents its aggregate capital, $M_{i, t}$ is the amount of immigrants living in it, $N_{i, t}$ characterizes its native workforce, $\theta_{s}(s=M, N)$ represent the efficiency units of labor of type $s$ and $\alpha \in[0,1]$ is the capital share.

The representative firm of each country rents capital from the international financial markets at the given interest rate $r_{t}{ }^{2}$ It also hires efficiency units of labor and pays each a wage $w$.

Equation (1) implies that native and immigrant efficiency units are perfect substitutes. However, recent structural estimates of the effect of immigration on wages based on CES production functions, however, assume complementarities among different skill levels (Borjas, 2003; Ottaviano and Peri, 2006). Unfortunately, data on education and/or experience of immigrants are not available. Therefore, the present paper only considers two types of labor (immigrants and natives). Moreover, they are included as substitutes, since introducing complementarities between them would imply adding an elasticity of substitution parameter that is not identified (there would be two parameters - elasticity of substitution and relative efficiency units per worker - for only one variable -immigration rate) ${ }^{3}$.

According to the maximization of the firm, the demand of capital is

$$
K_{i, t}=\left(\frac{\alpha}{r_{t}}\right)^{\frac{1}{1-\alpha}} L_{i, t}^{*} .
$$

Substituting (2) into (1) and with some derivations (see the Appendix A) we obtain the following regression equation:

$$
\Delta \ln y_{i, t}=\gamma \Delta \ln m_{i, t}+\eta_{i}+\tau_{t}+\varepsilon_{i, t},
$$

\footnotetext{
2 This assumption is plausible for OECD, especially in recent years, when a half of their countries (Eurozone members) have a common central bank.

3 In a generic case, efficiency units of labor would be given by $L_{i, t}^{*}=\left(\theta_{M} M_{i, t}^{\rho}+\theta_{N} N_{i, t}^{\rho}\right)^{\frac{1}{\rho}}$ in which the parameter $\rho$ is a sufficient statistic of the elasticity of substitution. In the present case $\rho=1$, which implies an elasticity of substitution that tends to infinity, implying perfect substitutability.
} 
in which $\gamma \equiv\left(\theta_{M N}-1\right) \bar{m}, \theta_{M N} \equiv \frac{\theta_{M}}{\theta_{N}}$ and $\bar{m}=\frac{1}{N T} \sum_{i, t} m_{i, t}$. Regarding the regression error, $\tau_{t}$ is a time fixed effect that is a function of the world interest rate; $\eta_{i}$ allow different growth rates for different countries that may be motivated by differences in the exogenous growth rate of technology ${ }^{4}$; finally, $\varepsilon_{i, t}$ is a transitory shock to productivity growth.

The parameter $\gamma$ determines the relationship between immigrant and native productivity. A negative value means that $\theta_{M N}<1$, which imply that immigrants are less productive than natives, and vice versa.

Immigration is likely to be endogenous in equation (3). Immigrants choose as a destination those countries that present higher productivity growth rates (both due to transitory shocks, $\varepsilon_{i, t}$, and to permanently higher exogenous growth rates of technology, included in $\eta_{i}$ ). Additionally, immigration from developing countries might be also correlated with OECD interest rates (included in $\tau_{t}$ ).

Several techniques are used to correct for OLS biases. Fixed (time invariant) heterogeneity is eliminated using within groups (WG). Moreover, in order to eliminate temporal (country invariant) fixed effects, equation (3) is estimated with the variables in deviations from cross-sectional and temporal means ${ }^{5}$. Finally, I introduce push-targeting instruments to eliminate the remaining endogeneity.

\section{$2.2 \quad$ Aggregation and push-targeting instruments}

Frankel and Romer (1999) introduced the instrumentation of international trade based on gravity equations. To this end, they estimated a bilateral trade equation using geographic regressors. Then, they aggregated its fitted values to obtain an instrument for trade in a productivity regression.

This kind of approach is suitable for immigration. However, the lack of bilateral migration data for a sufficiently large number of countries and periods makes its implementation difficult. Moreover, since geography is usually time-constant, its use in a panel data setting with fixed effects is not possible. The present paper proposes a solution to both problems: aggregation of instruments for the lack of

\footnotetext{
4 The exogenous growth rate of technology, for instance, may be introduced in the $\theta_{s}$ $(s=M, N)$ parameters. In order to have a constant parameter $\gamma$ we may assume that $\theta_{M i}$ and $\theta_{N i}$ grow at the same rate; if that is the case, $\theta_{M N}$ is constant but a fixed effect appears in the regression error.

5 This technique, indeed, consists in subtracting to each variable both its cross-sectional and temporal sample means, and adding up the overall mean to avoid the double subtraction of the constant term. In the case of a balanced panel, this procedure gives numerically equivalent results to WG with time dummies. However, with an unbalanced panel (as in this paper) this equivalence is only asymptotic, even though small sample differences are negligible.
} 
bilateral data and push-targeting interactions to obtain the variance that identify the second stage coefficient.

If we were able to follow the approach of Frankel and Romer (1999), the considered instruments for migration should have a bilateral nature:

$$
\Delta m_{i, j, t}=\delta^{\prime} b_{i, j, t}+u_{i, j, t}
$$

in which $b_{i, j, t}$ is a set of bilateral instruments and $u_{i, j, t}$ is the residual, orthogonal to the error term in equation (3). This first stage regression, however, is unfeasible, since bilateral data are not available. Conversely, we have aggregate data that satisfies:

$$
\Delta m_{i, t}=\sum_{j=1}^{J} \Delta m_{i, j, t}{ }^{6}
$$

The solution to the lack of bilateral data that is proposed in the present paper is the result of replacing (4) into (5):

$$
\Delta m_{i, t}=\sum_{j=1}^{J} \Delta m_{i, j, t}=\delta^{\prime} \sum_{j=1}^{J} b_{i, j, t}+\sum_{j=1}^{J} u_{i, j, t},
$$

or, in words, aggregating the instruments before regressing against immigration. By construction, exogeneity should still hold, since $u_{i, j, t}$ being orthogonal to the error term in (3) is a sufficient though not necessary condition for $\sum_{j=1}^{J} u_{i, j, t}$ being orthogonal. The only potential inconvenience of this procedure might be a loss in efficiency due to the reduction of degrees of freedom with respect to the bilateral case. In sum, the IV strategy entails finding bilateral instruments, aggregating each for all possible origins of immigrants and using the entire as an instrument.

The second concern to face up to is the absence of time variance of geographic instruments. Since temporal and country fixed effects are controlled for in the 2SLS regressions, the instruments have to vary across destinations and over time. As long as Frankel and Romer (1999) estimate their regression with a cross-section, their geographic time-constant instruments are valid. In the case of panel data

6 If we consider immigration in logarithms, the aggregate flow could be transformed into the following expression:

$$
\Delta \ln m_{i, t} \simeq \frac{m_{i, t}-m_{i, t-5}}{m_{i, t-5}}=\sum_{j=1}^{J} \frac{m_{i, j, t}-m_{i, j, t-5}}{m_{i, t-5}}=\frac{1}{m_{i, t-5}} \sum_{j=1}^{J} \Delta m_{i, j, t} .
$$

The only difference is that, in this expression, the bilateral flow is scaled by the country's migration rate at the beginning of the period. However, it is unlikely to affect the validity of the approach. 
with fixed effects, however, they are not useful to identify the second stage coefficient. Likewise, social, economic, demographic or political instruments from the origin country are not valid either, because they do not have variance across destinations.

In order to provide identification, the present paper proposes the interaction of both types of instruments. A shock to one of those variables from the origin country motivates the decision to migrate; thus, they may be considered as "push" instruments. Conversely, geographic components of gravity equations are good predictors of the choice of the destination country once migration decision is taken $^{7}$; for that reason we may refer to them as "targeting" instruments. Therefore, we could identify the interactions as push-targeting interactions.

This procedure generates a big set of candidates to instruments. They have variance across origins $(i)$, destinations $(j)$ and over time $(t)$. Therefore, they allow us to identify the second stage coefficient.

Table 1 lists the instruments that are considered; the following lines motivate their choice. Regarding population growth of the source country, a positive shock on it generates downward pressures on wages and employment scarcity. Therefore, it can stimulate migration since remaining into the country becomes less attractive.

Table 1: List of push and targeting instruments

\begin{tabular}{l|l}
\hline \hline \multicolumn{1}{c}{ Push } & \multicolumn{1}{c}{ Targeting } \\
\hline - Population growth & - Dummy for common language \\
- Wars and conflicts & - Dummy for past colonial relationship \\
- Political autocracy/democracy & - Log of product of areas \\
(polynomial) & - Log of geographic distance \\
& - Share of border formed by coast \\
\hline
\end{tabular}

Wars and conflicts motivate huge amounts of people to leave their countries fleeing from the tragedy. In order to ensure the exogeneity of the instrument, only civil conflicts are considered.

Polity IV rating ranges from 10 in a purely democratic regime to -10 in an extreme autocracy. This variable is introduced in the form of a second order

7 This two step decision is actually a theoretical digression. In reality, migrants choose simultaneously whether to migrate or not and the destination country; in fact, these geographic variables are also part of the cost of migration. 
polynomial. The motivation is that, despite migration is increasing with the degree of autocracy, it may be very difficult to depart from a very autocratic country since it often has closed frontiers.

Sharing a common language is a measure of the cultural distance among countries; moving costs are reduced if migrant speaks the language of the host country, since it facilitates integration, assimilation and initial procedures (finding a place to live, preparing job interviews, dealing with bureaucracy...). That is the motivation of the inclusion of a dummy variable that takes the value of one if a pair of countries shares a language.

Another important determiner of the cultural distance among countries is the presence of a past colonial relationship; countries with a past colonial relationship share a lot of cultural features that make integration easier. Moreover, colonial relationship is often associated with special (softer) policies of admission into the country.

Similar to the law of gravity in Physics, migration flows are negatively correlated with the distance between countries and positively with their size. The logarithm of the product of areas is a measure of the latter, whereas the logarithm of the geographic distance between the two countries measures the former.

Finally, the coast variable measures the share of a pair of countries' border that is formed by coast. For instance, if both countries are islands, its value is 1 ; if one of them is an island and the other is landlocked, then the variable takes the value of 0.5 and so on. Its inclusion is motivated by its association with moving costs: overland moving is often cheaper (and faster) than sea transportation, and air means of transport are an option in all cases.

\section{Data}

This section presents a description of the main features of the data and the sample. Appendix B provides the list of sources and definitions of all variables.

Figure 1 shows the evolution of immigration for all countries in the sample; different profiles emerge. Traditional immigration economies, such as Australia, Canada, New Zealand or the US maintained high migration rates very constant during the whole period ${ }^{8}$. Conversely, new immigration countries, like Austria,

\footnotetext{
8 This is especially true for Australia and Canada because they have target policies: they promote actively immigration when scheduled figures are not achieved and cut off excessively large flows.
} 
Figure 1: Immigrants, natives and immigrants' share of population
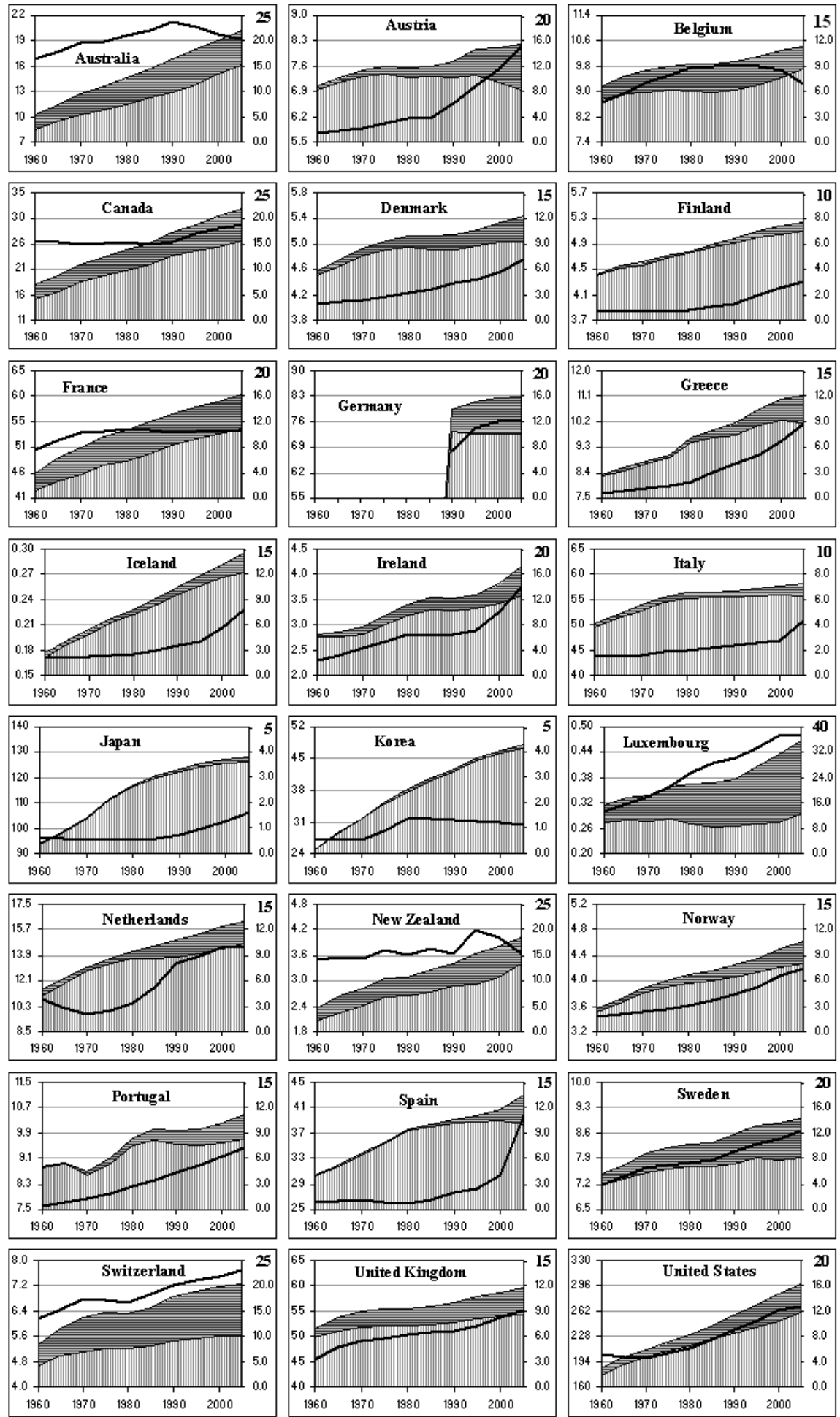

\begin{tabular}{rl}
1960 & 1970 \\
\hline
\end{tabular}

Source: own elaboration with data from United Nations (2006)

Left axis in milions Right axis in percentages 
Ireland, Spain or even Portugal, Greece and Italy, had had low immigration rates until recently, when they observed the landing of a big flow of immigrants. Asian countries (Japan and Korea) present very low immigration rates during the whole period. Finally, in most of the remaining countries, immigration avoided a zero population growth in several periods (Germany, Denmark, Sweden, Switzerland, Luxembourg and the United Kingdom).

Regarding the instruments, sources and descriptions of the variables are presented in Appendix B and a motivation of their choice is in Section 2.2. The following lines, however, describe how they are elaborated. The first step is to generate the interactions between each push and each targeting variable from those listed in Table 1. Then, interactions are aggregated over all available origins up to 187 countries $^{9}$. In the end, 20 potential candidates emerge.

Table 2: Summary statistics

\begin{tabular}{l|rrrrr|rrrr}
\hline \hline \multicolumn{10}{c}{ Second stage variables } \\
\hline Variable & Obs. & $\operatorname{Max} N$ & $\operatorname{Min} N$ & $\operatorname{Max} T$ & $\operatorname{Min} T$ & Mean & S.d. & Min & $\operatorname{Max}$ \\
\hline$\Delta \ln m$ & 210 & 24 & 23 & 9 & 3 & 0.132 & 0.166 & -0.336 & 1.023 \\
$\Delta \ln y$ & 210 & 24 & 23 & 9 & 3 & 0.023 & 0.020 & -0.016 & 0.097 \\
$\Delta \ln y^{p c}$ & 210 & 24 & 23 & 9 & 3 & 0.027 & 0.019 & -0.019 & 0.104 \\
$\Delta \ln l^{A}$ & 210 & 24 & 23 & 9 & 3 & 0.004 & 0.006 & -0.014 & 0.020 \\
$\Delta \ln (1-u)$ & 180 & 24 & 7 & 9 & 3 & -0.001 & 0.006 & -0.027 & 0.019 \\
\hline
\end{tabular}

First stage variables. Push

\begin{tabular}{l|rrrrr|rrrr}
\hline Variable & Obs. & Max $J$ & Min $J$ & MaxT & MinT & Mean & S.d. & Min & Max \\
\hline$\Delta \ln$ pop & 1692 & 188 & 188 & 9 & 9 & 0.016 & 0.015 & -0.091 & 0.148 \\
conflict & 1692 & 188 & 188 & 9 & 9 & 0.066 & 0.228 & 0 & 1 \\
$p I V$ & 1236 & 158 & 114 & 9 & 0 & 0.007 & 7.361 & -10 & 10 \\
\hline
\end{tabular}

First stage variables. Targeting

\begin{tabular}{l|rrrrr|rrrr}
\hline Variable & Obs. & $\operatorname{Max} N$ & $\operatorname{Min} N$ & $\operatorname{Max} J$ & $\operatorname{Min} J$ & Mean & S.d. & Min & $\operatorname{Max}$ \\
\hline comlang & 4488 & 24 & 24 & 187 & 187 & 0.105 & 0.307 & 0 & 1 \\
colony & 4488 & 24 & 24 & 187 & 187 & 0.045 & 0.207 & 0 & 1 \\
$\ln \left(A_{i} A_{j}\right)$ & 4368 & 24 & 0 & 182 & 182 & 23.805 & 3.049 & 13.562 & 32.768 \\
$\ln$ dist & 4017 & 24 & 0 & 172 & 149 & 8.238 & 0.821 & 4.797 & 9.810 \\
coast & 4488 & 24 & 24 & 187 & 187 & 0.546 & 0.262 & 0 & 1 \\
\hline
\end{tabular}

See sources and definitions of the variables in Appendix B. Max and $\min N$ represent the maximum and minimum number of countries with available data over all periods. The analogous for $T$ represent the maximum and minimum number of periods with available data over all countries. Finally, the same applies for origins, J. All statistics are calculated with pooled data.

Table 2 presents the summary statistics of the main variables and instruments. It shows that this paper uses an unbalanced panel with data for 24 richest OECD

9 In fact, they are averaged and multiplied by 187. This procedure avoids problems with the number of observations. 
countries and 9 five-year periods that range from 1960 to 2005. The missing observations are the first six periods for Germany and some other ones in the case of employment. Regarding the instruments, an important share of data points are covered. In particular, only one push and two targeting variables do not have all possible information. Finally, all variables seem to have variance enough to identify the correspondent coefficients.

\section{Results}

\subsection{First stage results}

The result of the interaction of the elements of each column of Table 1 is a set of 20 push-targeting candidates to instruments. Immigration $(\Delta \ln m)$ is regressed on all these aspirants with the purpose of choosing the relevant ones. In order to control for time and country fixed effects, the present paper estimates second stage regressions with the variables in deviations with respect to cross-sectional and temporal sample means; therefore, first stage ones are estimated in the same way.

Table 3 presents the first stage results. Regression (1) includes all candidates. In that regression, 10 candidates have coefficients significantly different from zero. Column (2) include only the nine interactions that are significant in column (1) (the tenth, $\ln \left(A_{i} A_{j}\right) * p I V^{2}$, have a non significant coefficient when is regressed only with the other nine candidates).

Instruments are jointly relevant. In particular, $R^{2}$ is above 0.25 in both cases (and adjusted $R^{2}$ is above 0.20 ), implying that instruments are sufficiently correlated with immigration flow. Moreover, $F$ statistic rejects the null hypothesis that all coefficients are jointly equal to zero.

Even though it is not necessary, checking the signs of the coefficients helps to motivate the choice of the instruments. The coefficient of an interaction is a non-linearity to the effect of each element of the interaction ${ }^{10}$. All coefficients in

\footnotetext{
10 In the present paper, first stage regressions are estimated with the variables in deviations with respect to cross-sectional and temporal sample means. Therefore, it is the non-linearity that the interaction introduces what identifies the second stage coefficient. For instance, an individual that flee an autocratic country is more likely to be accepted in a host country that has a past colonial relationship with the source country. An immigrant that departs from a democracy is able to be more selective with the destination and choose a country in which his or her language is spoken. And a conflict in an island is likely to crowd out fewer migrants than one in a landlocked country.
} 
Table 3: First stage results.

Dependent variable: $(\Delta \log$ of $)$ immigration rate $(\Delta \ln m)$

\begin{tabular}{|c|c|c|c|c|c|}
\hline Variable & (1) & $(2)$ & & & \\
\hline comlang $* \Delta \ln p o p$ & $\begin{array}{c}0.057 \\
(0.112)\end{array}$ & & & & \\
\hline comlang $*$ conflict & $\begin{array}{c}0.042 \\
(0.100)\end{array}$ & & $\ln d i s t * \Delta \ln p o p$ & $0.665^{* * *}$ & $0.472^{* * *}$ \\
\hline comlang $* p I V$ & $\begin{array}{l}0.382^{* *} \\
(0.154)\end{array}$ & $\begin{array}{c}0.308^{* * *} \\
(0.124)\end{array}$ & $\ln d i s t *$ conflict & $\begin{array}{c}(0.218) \\
0.103\end{array}$ & $(0.142)$ \\
\hline comlang $* p I V^{2}$ & $\begin{array}{l}0.353^{* *} \\
(0.174)\end{array}$ & $\begin{array}{l}0.303^{* *} \\
(0.122)\end{array}$ & $\ln d i s t * p I V$ & $\begin{array}{c}(0.091) \\
0.199\end{array}$ & \\
\hline colony $* \Delta \ln$ pop & $\begin{array}{l}-0.051 \\
(0.080)\end{array}$ & & $\ln d i s t * p I V^{2}$ & $\begin{array}{l}(0.220) \\
-0.051\end{array}$ & \\
\hline colony $*$ conflict & $\begin{array}{c}0.077 \\
(0.095)\end{array}$ & & coast $* \Delta \ln p o p$ & $\begin{array}{c}(0.138) \\
-0.482^{* *}\end{array}$ & $-0.243^{* * *}$ \\
\hline colony $* p I V$ & $\begin{array}{c}0.365^{* * *} \\
(0.130)\end{array}$ & $\begin{array}{c}0.318^{* * *} \\
(0.119)\end{array}$ & coast $*$ conflict & $\begin{array}{c}(0.235) \\
-0.269^{* * *}\end{array}$ & $\begin{array}{c}(0.078) \\
-0.195^{* * *}\end{array}$ \\
\hline colony $* p I V^{2}$ & $\begin{array}{l}0.219^{*} \\
(0.120)\end{array}$ & $\begin{array}{l}0.205^{* *} \\
(0.103)\end{array}$ & coast $* p I V$ & $\begin{array}{c}(0.082) \\
-0.198\end{array}$ & $(0.068)$ \\
\hline $\ln \left(A_{i} A_{j}\right) * \Delta \ln p o p$ & $\begin{array}{c}0.609 \\
(0.537)\end{array}$ & & coast $* p I V^{2}$ & $\begin{array}{l}(0.265) \\
-0.001\end{array}$ & \\
\hline $\ln \left(A_{i} A_{j}\right) *$ conflict & $\begin{array}{c}0.298^{* * *} \\
(0.107)\end{array}$ & $\begin{array}{c}0.226^{* * *} \\
(0.068)\end{array}$ & & $(0.136)$ & \\
\hline $\ln \left(A_{i} A_{j}\right) * p I V$ & $\begin{array}{l}1.018^{*} \\
(0.603)\end{array}$ & $\begin{array}{l}0.259^{*} \\
(0.146)\end{array}$ & $R^{2}$ & 0.290 & 0.261 \\
\hline $\ln \left(A_{i} A_{j}\right) * p I V^{2}$ & $\begin{array}{l}0.361^{*} \\
(0.205)\end{array}$ & & $\begin{array}{l}\text { Obs. } \\
F\end{array}$ & $\begin{array}{l}210 \\
2.94\end{array}$ & $\begin{array}{l}210 \\
4.51\end{array}$ \\
\hline
\end{tabular}

this first stage are interpretable.

In sum, nine candidates out of the 20 initial aspirants present relevance in the first stage. Therefore, the interactions push-targeting provide enough variance to identify the second stage coefficient. Moreover, aggregation of instruments seems unlikely to change de results since all signs are interpretable.

\subsection{The impact of immigration on productivity}

Table 4 presents the second stage results for regression (3). Column (1) shows OLS estimates. The coefficient of immigration is roughly zero. However, Section 2.1 argues that OLS estimates are likely to be biased; in particular, both fixed effects and the transitory shocks are probably correlated with immigration.

In a first correction, column (2) includes within-group estimates to eliminate country fixed effects. Despite the coefficient is still non-significantly different 
Table 4: The impact of immigration on productivity. Dependent variable: GDP per worker $(\Delta \ln y)$

\begin{tabular}{|c|c|c|c|c|c|c|}
\hline & (1) & $(2)$ & $(3)$ & (4) & $(5)$ & (6) \\
\hline$\Delta \ln m(\gamma)$ & $\begin{array}{c}0.001 \\
(0.009)\end{array}$ & $\begin{array}{l}-0.015 \\
(0.009)\end{array}$ & $\begin{array}{l}-0.009 \\
(0.007)\end{array}$ & $\begin{array}{l}-0.025^{*} \\
(0.013)\end{array}$ & $\begin{array}{l}-0.021^{*} \\
(0.012)\end{array}$ & $\begin{array}{l}-0.025^{*} \\
(0.013)\end{array}$ \\
\hline $\ln s a v$. & & & & & $\begin{array}{c}0.028^{* * *} \\
(0.010)\end{array}$ & \\
\hline$\Delta \ln L$ & & & & & $\begin{array}{c}0.240 \\
(0.336)\end{array}$ & $\begin{array}{c}-0.092 \\
(0.370)\end{array}$ \\
\hline $\ln y_{t-5}$ & & & & & $\begin{array}{c}-0.046^{* * *} \\
(0.006)\end{array}$ & \\
\hline$\Delta \ln \frac{(X+M)}{Y}$ & & & & & & $\begin{array}{c}0.048 \\
(0.063)\end{array}$ \\
\hline Constant & $\begin{array}{c}0.023^{* * *} \\
(0.002)\end{array}$ & $\begin{array}{c}0.025^{* * *} \\
(0.002)\end{array}$ & & & & \\
\hline Obs. & 210 & 210 & 210 & 210 & 210 & 210 \\
\hline Sargan & & & & 0.21 & 0.17 & 0.20 \\
\hline$\hat{\theta}_{M N}$ & $\begin{array}{c}1.013 \\
(0.120)\end{array}$ & $\begin{array}{c}0.800^{\dagger} \\
(0.120)\end{array}$ & $\begin{array}{c}0.880 \\
(0.093)\end{array}$ & $\begin{array}{c}0.667^{\dagger} \\
(0.173)\end{array}$ & $\begin{array}{c}0.720^{\dagger} \\
(0.160)\end{array}$ & $\begin{array}{c}0.667^{\dagger} \\
(0.173)\end{array}$ \\
\hline Country fixed effects & No & Yes & Yes & Yes & Yes & Yes \\
\hline Time fixed effects & No & No & Yes & Yes & Yes & Yes \\
\hline Technique & OLS & WG & WG & 2SLS & 2SLS & 2SLS \\
\hline
\end{tabular}

Robust standard errors in parentheses. Standard errors of $\hat{\theta}_{M N}$ calculated as that of $\gamma$ divided by $\bar{m}$ (taking the randomness in $\bar{m}$ into account makes no difference to the calculations). Significance levels: ${ }^{*} 10 \%^{* *} 5 \%{ }^{* * *} 1 \%$. A $\dagger$ implies that the coefficient is significantly different from one at $10 \%$ significance level. To eliminate both country and time fixed effects, correspondent regressions are estimated with the variables in deviations with respect to cross-sectional and temporal sample means. Constant term in column (2) represents the average of fixed effects. See sources and definitions of the variables in Appendix B.

from zero, it seems that country fixed effects biases OLS estimates upwards. This result is in line with the expected nature of the endogeneity, since it means that immigrants choose those destinations in which productivity and wages are higher.

Column (3) additionally corrects for endogeneity due to the time fixed effect. As it is described in Section 2.1, to correct for this bias, estimates are carried out with the variables in deviations with respect to cross-sectional and temporal sample means. Results suggest a negative correlation between the time fixed effect and immigration (downward bias) but the coefficient is still non-significantly different from zero.

In order to correct for the remaining regression bias, columns (4) to (6) present 2SLS estimates. Column (4) is the basic specification of equation (3) and columns (5) and (6) include some control variables to check whether the results are robust to the inclusion of additional variables. Results show that immigration is posi- 
tively correlated with the transitory shock in equation (3) (upward bias). This positive correlation is due to the same reverse causality argument that applies for the country fixed effect. Sargan tests confirm the validity of instruments, since their p-values are widely in the acceptance region of the null of orthogonality. Moreover, coefficients are roughly similar across specifications.

These estimates present a significantly negative coefficient for immigration. The relevant parameter, $\theta_{M N}$, included in $\gamma$ in equation (3), turns out to be significantly smaller than one. In particular, its value is around two thirds. This order of magnitude, however, should be taken carefully, since both temporal and cross-sectional dimensions of data are small (see Table 2).

The result $\theta_{M N}=2 / 3$ means that an immigrant produce two thirds of the efficiency units of a native. It may be motivated by a different composition of skills among immigrants and natives. Unfortunately, skill level of immigrants is not available and this statement cannot be verified. This outcome implies that an increase of the immigration rate by 10 percentage points reduces average wage by a $3.3 \%^{11}$.

At this point, it is worthy to recall that, because of the lack of education and experience data, a strong assumption lies behind this result: perfect substitutability between the two types of labor. As a result, the effect of immigration on natives' wages is zero, and the fall of the average wage is simply due to a higher weight of immigrants (that earn lower wages) in the population. This feature makes impossible the comparison of the results of this paper with some relevant contributions in the micro-wages literature as Borjas (2003) or Ottaviano and Peri (2006).

\subsection{Analyzing the effect on GDP per capita}

So far, we have focused on the impact of immigration on productivity. However, the effect on GDP per capita is also interesting for welfare analysis. Results on productivity are negative but the concern now is whether this is also true for output per capita.

Table 5 presents the estimates of equation (3) including GDP per capita as the dependent variable. The same endogeneity concerns appear in this case, as

\footnotetext{
11 To calculate this result, I assume that the wage of an efficiency unit equals its marginal product in equation (1); then, the average wage per worker is the price of the efficiency units times the average efficiency units per worker, which is a function of $m_{i, t}$. The resulting "elasticity" is $\frac{\partial \ln \bar{W}_{i, t}}{\partial m_{i, t}}=\left(\theta_{M N}-1\right)$.
} 
Table 5: The impact of immigration on GDP per capita. Dependent variable: GDP per capita $\left(\Delta \ln y^{p c}\right)$

\begin{tabular}{|c|c|c|c|c|c|c|}
\hline & $\overline{(1)}$ & $\overline{(2)}$ & $\overline{(3)}$ & $(4)$ & $(5)$ & $\overline{(6)}$ \\
\hline$\Delta \ln m$ & $\begin{array}{c}0.002 \\
(0.009)\end{array}$ & $\begin{array}{l}-0.010 \\
(0.009)\end{array}$ & $\begin{array}{l}-0.005 \\
(0.007)\end{array}$ & $\begin{array}{l}-0.021 \\
(0.013)\end{array}$ & $\begin{array}{l}-0.013 \\
(0.012)\end{array}$ & $\begin{array}{l}-0.020 \\
(0.013)\end{array}$ \\
\hline$\Delta \ln L$ & & & & & $\begin{array}{c}0.094 \\
(0.328)\end{array}$ & $\begin{array}{l}-0.164 \\
(0.365)\end{array}$ \\
\hline $\ln s a v$. & & & & & $\begin{array}{c}0.028^{* * *} \\
(0.010)\end{array}$ & \\
\hline $\ln y_{t-5}^{p c}$ & & & & & $\begin{array}{c}-0.039^{* * *} \\
(0.007)\end{array}$ & \\
\hline$\Delta \ln \frac{(X+M)}{Y}$ & & & & & & $\begin{array}{c}0.020 \\
(0.060)\end{array}$ \\
\hline Constant & $\begin{array}{c}0.027^{* * *} \\
(0.002) \\
\end{array}$ & $\begin{array}{c}0.028^{* * *} \\
(0.002) \\
\end{array}$ & & & & \\
\hline Obs. & 210 & 210 & 210 & 210 & 210 & 210 \\
\hline Sargan & & & & 0.35 & 0.11 & 0.33 \\
\hline Country fixed effects & No & Yes & Yes & Yes & Yes & Yes \\
\hline Time fixed effects & No & No & Yes & Yes & Yes & Yes \\
\hline Technique & OLS & WG & WG & 2SLS & 2SLS & 2SLS \\
\hline
\end{tabular}

well as the same solutions. Results are qualitatively similar to those for GDP per worker. However, the main difference is that the coefficient is less negative, turning out to be non-significantly different from zero.

The present paper uses the following two decompositions of GDP per capita to analyze the underlying reasons of this absence of effect on GDP per capita. On the one hand, if we allow people to remain outside the labor market, then GDP per capita can be split in:

$$
y^{p c}=\frac{Y}{L^{A}} \frac{L^{A}}{L} \equiv y \times a \Rightarrow \Delta \ln y^{p c}=\Delta \ln y+\Delta \ln a,
$$

in which $a$ is the participation rate. On the other hand, if we consider the presence of unemployment, the channels become three:

$$
y^{p c}=\frac{Y}{L^{E}} \frac{L^{E}}{L^{A}} \frac{L^{A}}{L} \equiv y^{E} \times(1-u) \times a \Rightarrow \Delta \ln y^{p c}=\Delta \ln y^{E}+\Delta \ln (1-u)+\Delta \ln a,
$$

where $u$ is the unemployment rate.

Given that the effect of immigration on GDP per capita is smaller than the one on GDP per worker, one might expect that immigration has a positive effect on participation, on employment or on both. 
Table 6: The impact of immigration on participation. Dependent variable: participation rate $(\Delta \ln a)$

\begin{tabular}{lcccc}
\hline \hline & $(1)$ & $(2)$ & $(3)$ & $(4)$ \\
\hline$\Delta \ln m$ & 0.001 & $0.005^{* *}$ & $0.005^{* *}$ & $0.012^{* * *}$ \\
& $(0.002)$ & $(0.002)$ & $(0.002)$ & $(0.004)$ \\
$\Delta \ln \frac{\text { female }}{\text { total workforce }}$ & $0.193^{* * *}$ & $0.178^{* * *}$ & $0.134^{* * *}$ & $0.139^{* * *}$ \\
& $(0.039)$ & $(0.027)$ & $(0.030)$ & $(0.028)$ \\
Constant & $0.002^{* * *}$ & $0.001^{* *}$ & & \\
& $(0.001)$ & $(0.001)$ & & \\
\hline Obs. & 210 & 210 & 210 & 210 \\
Sargan & & & & 0.29 \\
\hline Country fixed effects & No & Yes & Yes & Yes \\
Time fixed effects & No & No & Yes & Yes \\
Technique & OLS & WG & WG & 2 SLS \\
\hline Rob
\end{tabular}

Robust standard errors in parentheses. Significance levels: ${ }^{*} 10 \%^{* *}$ $5 \%{ }^{* * *} 1 \%$. To eliminate both country and time fixed effects, correspondent regressions are estimated with the variables in deviations with respect to cross-sectional and temporal sample means. Constant term in column (2) represents the average of fixed effects. Instruments containing $\ln \left(A_{i} A_{j}\right)$ in column (4) are not included due to endogeneity considerations (see discussion in text). See sources and definitions of the variables in Appendix B.

Table 6 presents the results for participation. Immigration may be endogenous in the regressions. The main reason is that the higher the participation rates, the higher the competition to find a job, and, therefore, the less attractive is the country as a destination for immigrants. Furthermore, a high dependence ratio implies a high demand of some welfare services that are often provided by immigrants. Hence, in this case, the bias is likely to be negative.

Results seem to confirm this prediction both in OLS and WG regressions. In column (4), push-targeting interactions are used again to correct for endogeneity ${ }^{12}$. Point estimates show a positive and significant effect that partially offsets the negative impact of immigration on productivity.

For the case of employment, Table 7 presents the results. Immigration is again likely to be endogenous in regressions. On the one hand, immigrants choose those countries with labor market institutions that provide a higher probability to find a job after their landing; they also migrate to countries that experience positive shocks on employment (upward bias). However, some institutions that offer special protection to workers (such as unemployment insurance, unions, minimum

\footnotetext{
12 The instruments that include the variable $\ln \left(A_{i} A_{j}\right)$ are removed because exclusion restrictions for them do not seem to hold. Host country's area is correlated with population density, which is positively correlated with competition in the labor market (Sargan tests confirmed this hypothesis).
} 
Table 7: The third channel: employment rates.

Dependent variable: employment rate $(\Delta \ln (1-u))$

\begin{tabular}{lcccc}
\hline \hline & $(1)$ & $(2)$ & $(3)$ & $(4)$ \\
\hline$\Delta \ln m$ & 0.003 & 0.006 & 0.006 & $0.013^{* *}$ \\
$\Delta \ln L$ & $(0.004)$ & $(0.003)$ & $(0.004)$ & $(0.005)$ \\
& 0.021 & -0.133 & -0.135 & $-0.213^{*}$ \\
Constant & $(0.075)$ & $(0.144)$ & $(0.120)$ & $(0.123)$ \\
& $-0.002^{* *}$ & -0.001 & & \\
\hline Obs. & $(0.001)$ & $(0.001)$ & & 180 \\
Sargan & 180 & 180 & 180 & 0.69 \\
\hline
\end{tabular}

Robust standard errors in parentheses. Significance levels: ${ }^{*} 10 \%{ }^{* *}$ $5 \%^{* * *} 1 \%$. To eliminate both country and time fixed effects, correspondent regressions are estimated with the variables in deviations with respect to cross-sectional and temporal sample means. Constant term in column (2) represents the average of fixed effects. Interactions comlang $* p I V^{2}$ and $\ln \left(A_{i} A_{j}\right) * p I V$ are not included in estimates of column (4) due to lack of relevance in the first stage with the new sample. See sources and definitions of the variables in Appendix B.

wages...) make the country more attractive to foreigners but may increase unemployment rates (downward bias). Therefore, the predicted sign of the bias is ambiguous in this case.

Unfortunately, only 180 observations of unemployment rates are available (see details in Table 2). Therefore, all above presented regressions were estimated again with the reduced sample to check whether outcomes were robust to sample changes (estimates are available from the author upon request). Results are very similar.

Table 7 seems to confirm endogeneity of immigration both in OLS and WG regressions. Those estimates seem to be downward biased. Therefore, the positive correlations with omitted institutional variables that generate unemployment seem to overcome other arguments. Results presented in column (4) correct for the endogeneity using push-targeting instruments. Point estimates show a positive significant effect that again offsets the negative effect of immigration on productivity.

This positive effect on employment is not new. For instance, Altonji and Card (1991) find evidence of a positive impact using metropolitan data. Immigrants both have a lower reservation wage and work in some sectors that may reduce reservation wages of natives. 


\subsection{Robustness checks}

This subsection presents some robustness analysis of the previous results, focusing on the choice of instruments. To this end, regressions presented in previous

Table 8: Robustness to the choice of instruments

\begin{tabular}{|c|c|c|c|c|c|c|c|}
\hline \multicolumn{8}{|c|}{ A. First stage results } \\
\hline & (1) & (2) & (3) & (4) & (5) & (6) & (7) \\
\hline \multirow[t]{2}{*}{ comlang $* p I V$} & & $0.550^{* * *}$ & $0.210^{*}$ & $0.340^{* * *}$ & $0.339^{* * *}$ & $0.302^{* *}$ & $0.310^{* *}$ \\
\hline & & $(0.177)$ & $(0.123)$ & $(0.120)$ & $(0.123)$ & $(0.133)$ & $(0.124)$ \\
\hline \multirow[t]{2}{*}{ comlang $* p I V^{2}$} & & $0.561^{* * *}$ & $0.218^{*}$ & $0.303^{* *}$ & $0.309^{* *}$ & $0.355^{* * *}$ & $0.328^{* * *}$ \\
\hline & & $(0.167)$ & $(0.121)$ & $(0.120)$ & $(0.121)$ & $(0.127)$ & $(0.121)$ \\
\hline \multirow[t]{2}{*}{ colony $* p I V$} & $0.483^{* * *}$ & & $0.386^{* * *}$ & $0.321^{* * *}$ & $0.323^{* * *}$ & $0.270^{* *}$ & $0.311^{* * *}$ \\
\hline & $(0.138)$ & & $(0.119)$ & $(0.117)$ & $(0.118)$ & $(0.119)$ & $(0.119)$ \\
\hline \multirow[t]{2}{*}{ colony $* p I V^{2}$} & $0.319^{* * *}$ & & $0.242^{* *}$ & $0.198^{*}$ & $0.179^{*}$ & 0.156 & $0.187^{*}$ \\
\hline & $(0.110)$ & & $(0.103)$ & $(0.102)$ & $(0.102)$ & $(0.098)$ & $(0.103)$ \\
\hline \multirow[t]{2}{*}{$\ln \left(A_{i} A_{j}\right) *$ conf } & $0.157^{* *}$ & $0.302^{* * *}$ & & $0.240^{* * *}$ & $0.185^{* * *}$ & $0.211^{* * *}$ & $0.134^{* *}$ \\
\hline & (0.063) & $(0.074)$ & & $(0.066)$ & $(0.064)$ & $(0.070)$ & $(0.060)$ \\
\hline \multirow{2}{*}{$\ln \left(A_{i} A_{j}\right) * p I V$} & $0.307^{* *}$ & $0.269^{*}$ & $0.308^{* *}$ & & $-0.168^{*}$ & $0.419^{* * *}$ & $0.335^{* *}$ \\
\hline & $(0.131)$ & $(0.149)$ & $(0.148)$ & & $(0.091)$ & $(0.135)$ & $(0.147)$ \\
\hline \multirow{2}{*}{$\ln d i s t * \Delta \ln p o p$} & $0.498^{* * *}$ & $0.479^{* * *}$ & $0.404^{* * *}$ & $0.265^{* * *}$ & & $0.491^{* * *}$ & $0.468^{* * *}$ \\
\hline & (0.139) & $(0.143)$ & (0.139) & $(0.078)$ & & $(0.142)$ & $(0.142)$ \\
\hline \multirow[t]{2}{*}{$\operatorname{coast} * \Delta \ln$ pop } & $-0.255^{* * *}$ & $-0.191^{* * *}$ & $-0.229^{* * *}$ & $-0.286^{* * *}$ & $-0.253^{* * *}$ & & $-0.145^{*}$ \\
\hline & $(0.074)$ & $(0.072)$ & $(0.080)$ & $(0.073)$ & $(0.084)$ & & $(0.074)$ \\
\hline \multirow{2}{*}{ coast $*$ conflict } & $-0.203^{* * *}$ & $-0.186^{* * *}$ & $-0.107^{*}$ & $-0.216^{* * *}$ & $-0.192^{* * *}$ & -0.095 & \\
\hline & $(0.068)$ & $(0.069)$ & $(0.063)$ & $(0.069)$ & $(0.070)$ & $(0.067)$ & \\
\hline Obs. & 210 & 210 & 210 & 210 & 210 & 210 & 210 \\
\hline \multirow[t]{2}{*}{$R^{2}$} & 0.236 & 0.222 & 0.236 & 0.253 & 0.230 & 0.232 & 0.239 \\
\hline & & B. $s$ & ond sta & results & & & \\
\hline \multirow{3}{*}{$\frac{\text { Dep.var. }}{\Delta \ln y}$} & (1) & (2) & (3) & (4) & (5) & (6) & (7) \\
\hline & -0.019 & $-0.022^{*}$ & $-0.026^{*}$ & $-0.026^{*}$ & $-0.029^{* *}$ & $-0.034^{* *}$ & $-0.033^{* *}$ \\
\hline & $(0.014)$ & $(0.013)$ & $(0.014)$ & $(0.013)$ & $(0.014)$ & $(0.015)$ & $(0.015)$ \\
\hline Sargan & 0.27 & 0.26 & 0.15 & 0.16 & 0.23 & 0.42 & 0.26 \\
\hline \multirow[t]{2}{*}{$\Delta \ln y^{p c}$} & -0.013 & -0.019 & -0.016 & -0.021 & $-0.024^{*}$ & $-0.029^{*}$ & $-0.027^{*}$ \\
\hline & $(0.014)$ & $(0.013)$ & $(0.013)$ & $(0.013)$ & $(0.014)$ & $(0.015)$ & $(0.015)$ \\
\hline \multirow{3}{*}{$\frac{\text { Sargan }}{\Delta \ln l}$} & 0.45 & 0.28 & 0.31 & 0.26 & 0.31 & 0.47 & 0.36 \\
\hline & $0.007^{*}$ & 0.004 & - & - & $0.013^{* * *}$ & $0.018^{* * *}$ & $0.014^{* * *}$ \\
\hline & $(0.004)$ & $(0.004)$ & - & - & $(0.004)$ & $(0.005)$ & $(0.004)$ \\
\hline Sargan & 0.00 & 0.01 & - & - & 0.22 & 0.72 & 0.27 \\
\hline \multirow{2}{*}{$\Delta \ln (1-u)$} & $0.016^{* *}$ & $0.017^{* *}$ & $0.020^{* * *}$ & $0.019^{* * *}$ & $0.015^{*}$ & $0.017^{* *}$ & \\
\hline & (0.007) & $(0.007)$ & $(0.007)$ & $(0.007)$ & (0.008) & $(0.007)$ & \\
\hline Sargan & 0.72 & 0.62 & 0.82 & 0.73 & 0.62 & 0.65 & \\
\hline
\end{tabular}

Robust standard errors in parentheses. Significance levels: ${ }^{*} 10 \%^{* *} 5 \%^{* * *} 1 \%$. Panel B coefficients are estimated by 2SLS controlling for time and country fixed effects (introducing the variables in deviations with respect to temporal and cross-sectional sample means). Controls are introduced as in column (4) of Tables 4 to 7. Instruments containing $\ln \left(A_{i} A_{j}\right)$ are not included in participation results due to endogeneity considerations (see Section 4.3). Employment estimates are performed using the sample of 180 countries (see Table 7); colony $* p I V^{2}$ and $\ln \left(A_{i} A_{j}\right) * p I V$ are not included in the instruments list of employment estimates due to the lack of relevance in the first stage with the reduced sample. Sargan p-values are provided after each second stage regression. See sources and definitions of the variables in Appendix B. 
subsections are estimated with different combinations of instruments. Table 8 presents the results.

First stage results are virtually unchanged; all variables are still significant, signs and order of magnitude are similar, and joint relevance is also the same. In second stage, the negative impact of immigration on productivity seems to be robust. The order of magnitude present small changes in some specifications, being non-significant in one case.

Conclusions for GDP per capita are virtually the same. In this case, there are some specifications in which the coefficient turns out to be significantly different from zero. For the case of participation, there are two regressions in which Sargan test rejects the null of validity of the exclusion restrictions; in fact, in these two cases, point estimates are quite smaller and non-significantly different from zero. The remaining columns show similar results to those from previous subsection. Finally, results for employment seem to be robust to the choice of instruments.

\section{Conclusions}

Immigration into OECD countries has experienced a sharp increase in recent years. This increase has attracted the attention of governments and economists. The present paper aims to give additional evidence on its consequences. To this end, it investigates the impact of immigration on productivity using cross-country panel data. Moreover, it analyzes the impact on GDP per capita, participation and employment. The estimates take reverse causality into account . To correct for these biases, the paper uses panel data techniques and instrumental variables.

The present investigation provides a new strategy to find instruments based on gravity equations. However, there are two drawbacks to be solved in the present context. On the one hand, bilateral migration data are not available. On the other hand, geography is constant over time and it cannot be used as instrument in a panel data setting with fixed effects. The current article gives a solution to both problems. It proposes the use of push-targeting instruments to obtain dynamic instruments to be used with fixed effects. Moreover, it suggests the aggregation of instruments as a solution to the lack of bilateral data.

The results of this paper suggest a negative impact of immigration on productivity. In particular, an immigrant produces about two thirds of the efficiency units of a native. Consequently, an increase of immigration rate of 10 percentage points reduce average wages by $3.3 \%$. This negative effect, however, is partially 
compensated by positive effects on participation and employment. In the end, the impact of immigration on GDP per capita turns out to be negative but nonsignificantly different from zero.

These results are complementary to those obtained in labor economics. Additionally, push-targeting instruments constitute the methodological contribution of this paper and might be useful in other fields. It can be presented as an alternative to the widely used stock of immigrants at the beginning of the period as instrument in the spatial correlations approach (Altonji and Card, 1991). It may also be useful in the trade literature to be used in panel data settings.

This paper focuses on impact; therefore, before taking policy conclusions, further research should be done on longer-term consequences of immigration (e.g., changes in investment and education patterns). Moreover, they are obtained under the assumption that immigrants and natives are perfect substitutes. This assumption has to be made because of the absence of macro data on skill level of immigrants for all countries and periods. These data would allow extending this paper to include complementarities. Finally, wages of natives do not change under the analysis of this paper because perfect capital mobility implies instantaneous adjustments of capital after an immigration shock. Labor economics research present evidence on the effect of immigration on natives' wages when capital is fixed but this is out of the scope of the paper.

\section{A Appendix: Some derivations}

This appendix describes, in a greater detail than in the main text, the derivations used to obtain (3). The representative firm of each country maximizes profits according to the production function

$$
Y_{i, t}=K_{i, t}^{\alpha}\left(\theta_{M} M_{i, t}+\theta_{N} N_{i, t}\right)^{1-\alpha} \equiv K_{i, t}^{\alpha}\left(L_{i, t}^{*}\right)^{1-\alpha}
$$

renting capital at the international interest rate $r_{t}$ and hiring efficiency units of labor at a wage $w$. Therefore, it faces the following maximization problem:

$$
\max _{K_{i, t}: L_{i, t}^{*}} K_{i, t}^{\alpha}\left(L_{i, t}^{*}\right)^{1-\alpha}-r_{t} K_{i, t}-w L_{i, t}^{*}
$$

The first order condition for capital is

$$
\alpha K_{i, t}^{\alpha-1}\left(L_{i, t}^{*}\right)^{1-\alpha}-r_{t}=0 \Rightarrow K_{i, t}=\left(\frac{\alpha}{r_{t}}\right)^{\frac{1}{1-\alpha}} L_{i, t}^{*} .
$$


Substituting (A.3) into (A.1) we obtain the following expression for output:

$$
Y_{i, t}=\left(\frac{\alpha}{r_{t}}\right)^{\frac{\alpha}{1-\alpha}}\left(\theta_{M} M_{i, t}+\theta_{N} N_{i, t}\right) .
$$

Therefore, output per worker is

$$
y_{i, t} \equiv \frac{Y_{i, t}}{L_{i, t}}=\left(\frac{\alpha}{r_{t}}\right)^{\frac{\alpha}{1-\alpha}} \theta_{N}\left(\theta_{M N} m_{i, t}+\left(1-m_{i, t}\right)\right)
$$

in which $L_{i, t}=M_{i, t}+N_{i, t}, m=\frac{M_{i, t}}{L_{i, t}}$ and $\theta_{M N}=\frac{\theta_{M}}{\theta_{N}}$.

Taking logs to the previous expression,

$$
\ln y_{i, t}=\ln \delta_{t}+\ln \left(1+\left(\theta_{M N}-1\right) m_{i, t}\right) \approx \ln \delta_{t}+\left(\theta_{M N}-1\right) m_{i, t} .
$$

Since $m_{i, t} \equiv \exp (\ln m)$, the second term can be approximated by the following Taylor expansion (around $\ln \bar{m}$ ):

$$
\left(\theta_{M N}-1\right) m_{i, t} \approx\left(\theta_{M N}-1\right) \bar{m} \ln m_{i, t}+\left(\theta_{M N}-1\right) \bar{m}(1-\ln \bar{m})
$$

and, therefore, (A.6) can be expressed as

$$
\ln y_{i, t}=\kappa+\ln \delta_{t}+\ln \left(1+\left(\theta_{M N}-1\right) m_{i, t}\right) \approx \ln \delta_{t}+\left(\theta_{M N}-1\right) \bar{m} \ln m_{i, t} .
$$

Adding a regression error and taking first differences, one may arrive to the desired result. 


\section{B Appendix: Data sources}

The following Table describes all data sources and the manipulations that I have done to the raw data of each source.

Table B.1: Data sources and definitions

\begin{tabular}{|c|c|c|c|c|}
\hline Variable & Name & Source & & Description \\
\hline$\Delta \ln m$ & Migration rate & $\begin{array}{l}\text { United } \\
(2006)\end{array}$ & Nations & $\begin{array}{l}\text { UN provides data on stocks of immigrants } \\
\text { for each country and period. These data } \\
\text { were obtained from national censuses, con- } \\
\text { sidering, whenever it is possible, foreign } \\
\text { born population as immigrant. The figures } \\
\text { measure the stock in the middle of the con- } \\
\text { sidered year, using interpolation when cen- } \\
\text { sus was made at a different point in time. } \\
\text { I constructed migration rates using popu- } \\
\text { lation figures from the same source. }\end{array}$ \\
\hline
\end{tabular}

Second stage variables

\begin{tabular}{|c|c|c|c|}
\hline$\Delta \ln y$ & Productivity & Heston et al. (2006) & $\begin{array}{l}\text { Real GDP per worker at PPP. Data finish } \\
\text { at } 2003 \text { and annual growth rates for the last } \\
\text { period are calculated from } 2000 \text { to } 2003 \text {. }\end{array}$ \\
\hline$\Delta \ln y^{p c}$ & GDP per capita & Heston et al. (2006) & $\begin{array}{l}\text { Real GDP per capita at PPP. Data finish } \\
\text { at } 2004 \text { and annual growth rates for the last } \\
\text { period are calculated from } 2000 \text { to } 2004 \text {. }\end{array}$ \\
\hline$\Delta \ln L$ & Population & Heston et al. (2006) & $\begin{array}{l}\text { Population. Data finish at } 2004 \text { and annual } \\
\text { growth rates for the last period are calcu- } \\
\text { lated from } 2000 \text { to } 2004 \text {. }\end{array}$ \\
\hline$\Delta \ln L^{A}$ & $\begin{array}{l}\text { Active popula- } \\
\text { tion }\end{array}$ & Heston et al. (2006) & $\begin{array}{l}\text { Workforce. Data finish at } 2003 \text { and annual } \\
\text { growth rates for the last period are calcu- } \\
\text { lated from } 2000 \text { to } 2003 \text {. }\end{array}$ \\
\hline$\Delta \ln l^{A}$ & $\begin{array}{l}\text { Active popula- } \\
\text { tion share }\end{array}$ & Heston et al. (2006) & This variable is defined as $l^{A}=\frac{L^{A}}{L}$. \\
\hline$\Delta \ln (1-u)$ & $\begin{array}{l}\text { Employment } \\
\text { rate }\end{array}$ & OECD (2006) & $\begin{array}{l}\text { Calculated as } 1 \text { minus unemployment rate. } \\
\text { This series starts in } 1970 \text {, so labor force sur- } \\
\text { vey data also provided by OECD is used to } \\
\text { complete the largest amount of gaps in the } \\
\text { series. In the end, } 180 \text { observations are ob- } \\
\text { tained, } 30 \text { less than in the general case. All } \\
\text { missing observations are for the two first } \\
\text { year periods (with the exception of Ger- } \\
\text { many, whose data for most of the variables, } \\
\text { as it is said in the main text, starts in 1990). }\end{array}$ \\
\hline$\Delta \ln y^{E}$ & $\begin{array}{l}\text { GDP per em- } \\
\text { ployee }\end{array}$ & $\begin{array}{l}\text { Heston et al. (2006) } \\
\text { and OECD (2006) }\end{array}$ & $\begin{array}{l}\text { Real GDP employed worker at PPP. Cal- } \\
\text { culated using }(1-u) \text { described just above } \\
\text { and population and real GDP from Heston } \\
\text { et al. (2006). }\end{array}$ \\
\hline
\end{tabular}

Continue next page... 
Table B.1 continued

\begin{tabular}{|c|c|c|c|}
\hline Variable & Description & Source & Description \\
\hline $\ln s a v$. & Savings rate & Heston et al. (2006) & $\begin{array}{l}\text { Investment over GDP. Data are averaged } \\
\text { for the five-year period. Regarding the last } \\
\text { period, data finish at } 2004 \text { and the average } \\
\text { is calculated from } 2000 \text { to } 2004 \text {. }\end{array}$ \\
\hline$\Delta \ln \frac{X+M}{Y}$ & Trade share & Heston et al. (2006) & $\begin{array}{l}\text { Exports plus imports over GDP. Data finish } \\
\text { at } 2004 \text { and annual growth rates for the last } \\
\text { period are calculated from } 2000 \text { to } 2004 \text {. }\end{array}$ \\
\hline$\Delta \ln \frac{\text { female }}{\text { tot.workf. }}$ & $\begin{array}{l}\text { Female partici- } \\
\text { pation }\end{array}$ & $\begin{array}{l}\text { International } \\
\text { Labour Organi- } \\
\text { zation (2007) }\end{array}$ & $\begin{array}{l}\text { Female workforce over total workforce. } \\
\text { When the exact year is not available, the } \\
\text { nearest is considered. }\end{array}$ \\
\hline
\end{tabular}

First stage variables

\begin{tabular}{lll}
\hline$\Delta \ln$ pop & $\begin{array}{l}\text { Population } \\
\text { growth }\end{array}$ & Heston et al. (2006) \\
\hline conflict & Conflict & $\begin{array}{l}\text { Own elaboration us- } \\
\text { ing Collier and Ho- } \\
\text { effler (2002) }\end{array}$
\end{tabular}

Population annual growth rate of the source country. All 187 considered origins are available for all periods.

Share of months in the five-year period that the country had a major internal conflict or war. Collier and Hoeffler (2002) provide beginning and ending dates of all major conflicts from 1960 to 1999 and using these data, I constructed the just described variable. According to their definition, "a civil war [...] is [...] an internal conflict with at least 1,000 combat-related deaths, with both an identifiable rebel organization and government forces suffering at least five percent of these casualties" (Collier and Hoeffler, 2002, p.3). I updated this database to the 2000-2005 period searching for conflicts in accordance with this definition. The whole sample includes 85 conflict periods that affected 53 countries.

\begin{tabular}{llll}
\hline$p I V$ & and & Second order & Center for Interna- \\
$p I V^{2}$ & & polynomial in tional Development \\
& Polity IV rating & \& Conflict Manage- \\
& & ment (2006)
\end{tabular}
Polity IV rating ranges from 10 (pure democracy) to -10 (pure autocracy) (For further details on its elaboration and sources, see Dataset Users' Manual, available on Internet with the dataset.). The considered variable is the average of Polity IV rating for each five-year period; the number of observations ranges from 114 in 1960 to 157 in 2000. 
Table B.1 continued

\begin{tabular}{|c|c|c|c|}
\hline Variable & Description & Source & Description \\
\hline comlang & $\begin{array}{l}\text { Common lan- } \\
\text { guage dummy }\end{array}$ & $\begin{array}{l}\text { Own elaboration us- } \\
\text { ing Alesina et al. } \\
(2003)\end{array}$ & $\begin{array}{l}\text { Dummy variable that takes value of one if } \\
\text { both countries of a pair share a language. } \\
\text { Alesina et al. (2003) list, for each coun- } \\
\text { try, the spoken languages and the shares } \\
\text { of speakers of each one (they collected data } \\
\text { from CIA). I consider that a pair of coun- } \\
\text { tries shares a particular language if that } \\
\text { language is spoken by at least a } 10 \% \text { of the } \\
\text { population in each country (with the excep- } \\
\text { tion of countries having a lingua franca, in } \\
\text { which case, for that language, the previous } \\
\text { limit does not bind). }\end{array}$ \\
\hline colony & $\begin{array}{l}\text { Past colonial } \\
\text { relationship } \\
\text { dummy }\end{array}$ & Own elaboration & $\begin{array}{l}\text { Dummy variable that takes value of one } \\
\text { if the pair of countries was in colonial re- } \\
\text { lationship in the past, either if the host } \\
\text { country was the metropolis or if it was the } \\
\text { colony (Australia, Canada, New Zealand } \\
\text { and the US, for example, were British } \\
\text { colonies). In this case, there is not a uni- } \\
\text { fied source, since I constructed the dummy } \\
\text { using the history of each country. This vari- } \\
\text { able includes all relevant colonial relation- } \\
\text { ships, not only the last one as those vari- } \\
\text { ables based on CIA (2007) do. }\end{array}$ \\
\hline $\ln \left(A_{i} A_{j}\right)$ & $\begin{array}{l}\text { Product of Ar- } \\
\text { eas }\end{array}$ & World Bank (2006) & Product of countries' surfaces in $\mathrm{km}^{2}$. \\
\hline $\ln$ dist & Distance & Rose (2004) & $\begin{array}{l}\text { Geographical distance among a pair of } \\
\text { countries in kilometers. The considered } \\
\text { definition of distance is the great circle one, } \\
\text { made available by Rose }(2004) \text {, that I ex- } \\
\text { tended to a larger number of countries. }\end{array}$ \\
\hline coast & $\begin{array}{l}\text { Share of border } \\
\text { formed by coast }\end{array}$ & $\begin{array}{l}\text { Own elaboration us- } \\
\text { ing CIA (2007) }\end{array}$ & $\begin{array}{l}\text { Share of a pair of countries' border that is } \\
\text { formed by coast. For instance, if both coun- } \\
\text { tries are islands, its value is } 1 \text {, but if one } \\
\text { of them is an island and the other is land- } \\
\text { locked, then the variable takes the value } \\
\text { of } 0.5 \text {. Therefore, it includes two recur- } \\
\text { rently used variables in trade literature, be- } \\
\text { ing landlocked and being an island, but also } \\
\text { all intermediate cases. I elaborated this } \\
\text { variable using country profiles from CIA } \\
\text { The World Factbook (CIA, 2007), and cal- } \\
\text { culating the share. }\end{array}$ \\
\hline
\end{tabular}

All variables are included in deviations with respect to temporal and cross-sectional means when indicated in the correspondent table. The symbol $\Delta$ means that the variables are considered in first differences, and $\ln$ is the natural logarithm. The variables indicated with $\Delta \ln$ are considered in annual growth rates. 


\section{References}

Alesina, Alberto, Arnaud Devleeschauwer, William E. Easterly, Sergio Kurlat, and Romain Wacziarg, "Fractionalization," Journal of Economic Growth, 2003, 8 (2), 155-194.

Altonji, Joseph G. and David E. Card, "The Effects of Immigration on the Labor Market Outcomes of Less-skilled Natives," in John M. Abowd and Richard B. Freeman, eds., Immigration, Trade and the Labor Market, Chicago, University of Chicago Press, 1991, pp. 201-234.

Barro, Robert J. and Xavier Sala-i-Martín, "Regional Growth and Migration: a Japan-U.S. Comparison," Journal of the Japanese and international economies, 1992, 6 (4), 312-346.

_ and _, Economic Growth, New York, McGraw-Hill, 1995.

Borjas, George J., "The Economic Analysis of Immigration," in Orley C. Ashenfelter and David E. Card, eds., Handbook of Labor Economics, Vol. 3A, Amsterdam, North-Holland, 1999.

_ , "The Labor Demand Curve Is Downward Sloping: Reexamining the Impact of Immigration on the Labor Market," Quarterly Journal of Economics, 2003, 118 (4), 1335-1374.

Braun, Juan, "Essays on Economic Growth and Migration." PhD dissertation, Harvard University 1993.

Center for International Development \& Conflict Management, "Polity IV," Data in digital form available on Internet, CIDCM, University of Maryland, College Park 2006.

CIA, "The World Factbook," Central Intelligence Agency (CIA), Washington DC 2007.

Collier, Paul and Anke Hoeffler, "Greed and Grievance in Civil War," 2002. Center for the Study of African Economies Working Papers, WPS 2002-01.

Drinkwater, Stephen, Paul Levine, Emanuela Lotti, and Joseph Pearlman, "The Economic Impact of Migration: A Survey," 2003. 
Flowenla Discussion Paper 8, Hamburg Institute of International Economics (HWWA).

Frankel, Jeffrey A. and David Romer, "Does Trade Cause Growth?," American Economic Review, 1999, 89 (3), 379-399.

Friedberg, Rachel M. and Jennifer Hunt, "The Impact of Immigrants on Host Country Wages, Employment and Growth," Journal of Economic Perspectives, 1995, 9 (2), 23-44.

Heston, Alan, Robert Summers, and Bettina Aten, "Penn World Table Version 6.2," Center for International Comparisons of Production, Income and Prices at the University of Pennsylvania 2006.

International Labour Organization, "LABORSTA, Labour Statistics Database," Data in digital form available on the Internet, (http://laborsta.ilo.org/). International Labour Organization, Geneva 2007.

OECD, "OECD Economic Outlook," Table S-13, Data in digital form made available by "dx for Windows", OECD, Paris 2006.

Ottaviano, Gianmarco I.P. and Giovanni Peri, "Rethinking the Effects of Immigration on Wages," 2006.

NBER Working Paper n.2497.

Rose, Andrew K., "Do We Really Know That the WTO Increases Trade?," American Economic Review, 2004, 94 (1), 98-114.

United Nations, "Trends in the Total Migrant Stock: The 2005 Revision," Data in digital form available on the Internet, (United Nations, POP/DB/MIG/Rev.2005) Population division, United Nations, New York 2006.

World Bank, "World Development Indicators, 2005," Data in digital form available on CD-ROM, World Bank, Washington DC. 2006. 


\section{CEMFI WORKING PAPERS}

0601 Beatriz Domínguez, Juan José Ganuza and Gerard Llobet: "R\&D in the pharmaceutical industry: a world of small innovations".

0602 Guillermo Caruana and Liran Einav: "Production targets".

0603 Jose Ceron and Javier Suarez: "Hot and cold housing markets: International evidence".

0604 Gerard Llobet and Michael Manove: "Network size and network capture".

0605 Abel Elizalde: "Credit risk models I: Default correlation in intensity models".

0606 Abel Elizalde: "Credit risk models II: Structural models".

0607 Abel Elizalde: "Credit risk models III: Reconciliation reduced - structural models".

0608 Abel Elizalde: "Credit risk models IV: Understanding and pricing CDOs".

0609 Gema Zamarro: "Accounting for heterogeneous returns in sequential schooling decisions".

0610 Max Bruche: "Estimating structural models of corporate bond prices".

0611 Javier Díaz-Giménez and Josep Pijoan-Mas: "Flat tax reforms in the U.S.: A boon for the income poor".

0612 Max Bruche and Carlos González-Aguado: "Recovery rates, default probabilities and the credit cycle".

0613 Manuel Arellano and Jinyong Hahn: "A likelihood-based approximate solution to the incidental parameter problem in dynamic nonlinear models with multiple effects".

0614 Manuel Arellano and Stéphane Bonhomme: "Robust priors in nonlinear panel data models".

0615 Laura Crespo: "Caring for parents and employment status of European mid-life women".

0701 Damien Geradin, Anne Layne-Farrar and A. Jorge Padilla: "Royalty stacking in high tech industries: separating myth from reality".

0702 Anne Layne-Farrar, A. Jorge Padilla and Richard Schmalensee: "Pricing patents for licensing in standard setting organizations: Making sense of FRAND commitments".

0703 Damien Geradin, Anne Layne-Farrar and A. Jorge Padilla: "The ex ante auction model for the control of market power in standard setting organizations".

0704 Abel Elizalde: "From Basel I to Basel II: An analysis of the three pillars".

0705 Claudio Michelacci and Josep Pijoan-Mas: "The effects of labor market conditions on working time: the US-UE experience".

0706 Robert J. Aumann and Roberto Serrano: "An economic index of riskiness".

0707 Roberto Serrano: "El uso de sistemas dinámicos estocásticos en la Teoría de Juegos y la Economía".

0708 Antonio Cabrales and Roberto Serrano: "Implementation in adaptive betterresponse dynamics".

0709 Roberto Serrano: "Cooperative games: Core and Shapley value".

0710 Allan M. Feldman and Roberto Serrano: "Arrow's impossibility theorem: Preference diversity in a single-profile world". 
0711 Victor Aguirregabiria and Pedro Mira: "Dynamic discrete choice structural models: A Survey".

0712 Rene Saran and Roberto Serrano: "The evolution of bidding behaviour in private-values auctions and double auctions".

0713 Gabriele Fiorentini and Enrique Sentana: "On the efficiency and consistency of likelihood estimation in multivariate conditionally heteroskedastic dynamic regression models".

0714 Antonio Díaz de los Ríos and Enrique Sentana: "Testing uncovered interest parity: A continuous-time approach".

0715 Francisco Peñaranda and Enrique Sentana: "Duality in mean-variance frontiers with conditioning information".

0716 Stefano Gagliarducci, Tommaso Nannicini and Paolo Naticchioni: "Electoral rules and politicians' behavior: A micro test".

0717 Laura Hospido: "Modelling heterogeneity and dynamics in the volatility of individual wages".

0718 Samuel Bentolila, Juan J. Dolado and Juan F. Jimeno: "Does immigration affect the Phillips curve? Some evidence for Spain".

0719 Enrique Moral-Benito: "Determinants of economic growth: A Bayesian panel data approach".

0801 David Martinez-Miera and Rafael Repullo: "Does competition reduce the risk of bank failure?".

0802 Joan Llull: "The impact of immigration on productivity". 